\title{
The glass formation and crystallization studies on iron phosphate- silicate glasses
}

\author{
Justyna Kuczek ${ }^{1} \cdot$ Justyna Sułowska ${ }^{1} \cdot$ Radosław Lach $^{1} \cdot$ Magdalena Szumera ${ }^{1}$
}

Received: 1 November 2018 / Accepted: 25 June 2019/Published online: 13 July 2019

(C) The Author(s) 2019

\begin{abstract}
The assessment of impact of incorporation of various amount of $\mathrm{Fe}_{2} \mathrm{O}_{3}$ at the expense of $\mathrm{MgO}$ and $\mathrm{CaO}$ on the glassy phase formation and thermal stability exhibited in $\mathrm{P}_{2} \mathrm{O}_{5}-\mathrm{SiO}_{2}-\mathrm{K}_{2} \mathrm{O}-\mathrm{MgO}-\mathrm{CaO}-\mathrm{Fe}_{2} \mathrm{O}_{3}$ system was carried out. The characteristic temperatures for iron phosphate-silicate glasses and glass-crystalline materials were designated from associated DSC curves. Selected samples were subjected to the process of induced crystallization, and products combined with particular exothermic effects were identified. Combination of DSC, XRD and SEM-EDS methods enabled to collect invaluable data concerning the course of crystallization of not only iron phosphate-silicate glasses subjected to the process of induced crystallization, but also glass-crystalline materials obtained directly through melt-quenched technique. The amount of particular crystalline products associated with selected devitrificates was determined via Rietveld technique. Results of the conducted study indicated that $\mathrm{Fe}_{2} \mathrm{O}_{3}$ addition conduces to the decrease in crystallization temperatures and thermal stability which was reflected in calculated values of $\Delta T$ and $K_{\mathrm{W}}$ parameters. Concomitantly, glass with $20 \mathrm{~mol} \%$ iron (III) oxide addition exhibited significantly improved, distinctive thermal stability among the materials in the analyzed series. The connection of crystalline phases with gradual alterations in polymerization degree of glass matrix was also established. The performed study is a contribution to the knowledge of iron phosphate glasses family and associated glass-crystalline materials.
\end{abstract}

Keywords Glass-forming ability $\cdot$ Crystallization process $\cdot \mathrm{Fe}_{2} \mathrm{O}_{3} \cdot$ Iron phosphate-silicate glasses

\section{Introduction}

Extensive research conducted on amorphous phosphate solids indicated their interesting fundamental properties. Various phosphate glasses with appropriate chemical composition were considered to be applicable in laser devices [1-4], as highly toxic, radioactive waste storage [5-7] and hermetic seals [5, 8], in electrochemical devices [9], for biomedical usage [10-13], [8]. Nevertheless, their practical use is limited because of poor chemical durability and difficulties in obtaining glassy material resulted from

Justyna Kuczek

jkuczek@agh.edu.pl

$\checkmark$ Magdalena Szumera

mszumera@agh.edu.pl

1 Faculty of Material Science and Ceramics, AGH University of Science and Technology, Al. Mickiewicza 30, 30-059 Cracow, Poland the tendency to crystallization exhibited during processing [8].

It was confirmed that iron (III) oxide addition conduces to the significant improvement of chemical durability. As an example of the utility, the application as nuclear waste host can be mentioned [14, 15]. Moreover, in [15] the increase in counteraction to crystallization in lead metaphosphate glass along with iron ions incorporation was also stated.

Thermal characteristics of phosphate glasses from the simple $\mathrm{P}_{2} \mathrm{O}_{5}-\mathrm{Fe}_{2} \mathrm{O}_{3}$ system [16] indicate that the crystallization of iron phosphate glasses runs in two stages, and the $\mathrm{Fe}^{2+} / \mathrm{Fe}^{3+}$ ratio is an important factor which has an influence on this process. The dominant crystalline phases produced by heat treatment are $\mathrm{Fe}_{3}\left(\mathrm{PO}_{4}\right)_{2}$ and $\mathrm{FePO}_{4}$, respectively. During the heat treatment of iron phosphate glasses, crystallization of by-products such as $\mathrm{Fe}_{2} \mathrm{O}_{3}, \mathrm{FeO}, \mathrm{Fe}_{3}\left(\mathrm{PO}_{4}\right)_{2} \cdot x \mathrm{H}_{2} \mathrm{O}$ and $\mathrm{FePO}_{4} \cdot x \mathrm{H}_{2} \mathrm{O}$ was concluded. The modification of the composition of this two-component system by addition of 
$\mathrm{CaO}$ causes a change in their thermal characteristics. Results of analysis of $x \mathrm{CaO}-(40-x) \mathrm{Fe}_{2} \mathrm{O}_{3}-60 \mathrm{P}_{2} \mathrm{O}_{5}$ glasses [17] indicate that with the addition of $\mathrm{CaO}$, thermal stability $(\Delta T)$ calculated from the difference between the glass transition and crystallization temperature increases from $79{ }^{\circ} \mathrm{C}(x=0)$ to $96{ }^{\circ} \mathrm{C}(x=40)$. Simultaneously, temperature of crystallization tends to increase to the certain point from $596{ }^{\circ} \mathrm{C}$ $(x=0)$ to $660{ }^{\circ} \mathrm{C}(x=24)$ and then decrease $\left(628{ }^{\circ} \mathrm{C}\right.$ for $x=40$ ). As it turns out, substitution of $\mathrm{CaO}$ in the analyzed system by $\mathrm{MgO}$ does not cause significant changes in the thermal characteristics. Glasses from $(40-x) \mathrm{MgO}-x \mathrm{Fe}_{2}$ $\mathrm{O}_{3}-60 \mathrm{P}_{2} \mathrm{O}_{5}$ system were also analyzed in [18] which exhibited similar tendency. Magnesium ions implementation is associated with the alteration of thermal stability from $61{ }^{\circ} \mathrm{C}(x=40)$ to $239{ }^{\circ} \mathrm{C}(x=0)$ and temperature of the first crystallization effect from $560{ }^{\circ} \mathrm{C}(x=0)$ to $784{ }^{\circ} \mathrm{C}$ $(x=40)$. Additionally, the products of crystallization were also stated as $\mathrm{Mg}\left(\mathrm{PO}_{3}\right)_{2}(x=0), \mathrm{Fe}\left(\mathrm{PO}_{3}\right)_{3}(x=10), \mathrm{Fe}_{3}(-$ $\left.\mathrm{P}_{2} \mathrm{O}_{7}\right)_{2}(x=20)$ and $\mathrm{FePO}_{4}(x=30)$ [18].

The aim of this work is to designate the glass-forming ability exhibited in analyzed system, gather the information about the course of crystallization, identify the associated crystalline products and their connection with structural changes deduced from spectroscopic studies described in [19] and delineate thermal characteristics of glass-crystalline materials with chemical composition not included in glass-forming region.

\section{Experimental}

Iron phosphate-silicate glasses and associated glass-crystalline materials from $\mathrm{P}_{2} \mathrm{O}_{5}-\mathrm{SiO}_{2}-\mathrm{K}_{2} \mathrm{O}-\mathrm{MgO}-\mathrm{CaO}-\mathrm{Fe}_{2} \mathrm{O}_{3}$ system were prepared via melt-quenched technique. The molar ratios of $\mathrm{P}_{2} \mathrm{O}_{5} / \mathrm{SiO}_{2}$ and $\mathrm{MgO} / \mathrm{CaO}$ were set as 41:6 and 1.5:1. Each material is named with the preservation of information about the molar content of $\mathrm{Fe}_{2} \mathrm{O}_{3}$ (for example, $2 \mathrm{Fe} 41 \mathrm{P}$ corresponds to $2 \mathrm{~mol} \% \mathrm{Fe}_{2} \mathrm{O}_{3}$ addition). Batches were prepared through mixing of high-purity ammonium dihydrogen phosphate, silicon dioxide, potassium carbonate, calcium carbonate, magnesium oxide and ferric oxide in ceramic mortar with a pestle in order to obtain desirable homogeneity. The losses concluded from volatility were also taken into account. Batches were melted in a ceramic crucible at $1100{ }^{\circ} \mathrm{C}$ in electrical furnace in air atmosphere and quenched by pouring on a steel plate which results in obtaining the materials characterized by similar thermal history.

Chemical composition of four distinctive amorphous solids with 2, 8, 15 and $30 \mathrm{~mol} \%$ iron (III) oxide addition and the confirmation of their amorphous state can be also found in [19]. The obtained materials are considered compatible with the assumptions. Moreover, amorphous state of additional materials was examined via X-ray diffraction analysis. The results are exemplified in Table 1.

Thermal stability was determined by differential scanning calorimetry (DSC) measurements conducted on Netzsch STA 449 F3 Jupiter 7 operating in the heat flux DSC mode. The temperature and heat calibrations of the instrument were performed using the melting temperatures and melting enthalpies of high-purity materials (Al, Zn, Sn, $\mathrm{Au}$ and $\mathrm{Ag}$ ). Forty-five milligrams of carefully weighed samples was heated in platinum crucibles at $10{ }^{\circ} \mathrm{C} \mathrm{min}{ }^{-1}$ in air atmosphere up to $1100{ }^{\circ} \mathrm{C}$. The glass transformation temperature $T_{\mathrm{g}}$ was determined as the midpoint of the $c_{\mathrm{p}}$ changes in the glass transformation region. The crystallization temperatures $T_{\mathrm{c} 1}$ and $T_{\mathrm{c} 2}$ were ascertain at the maximum deflection point of the exothermal effect. Further
Table 1 Nominal chemical composition of analyzed materials from $\mathrm{P}_{2} \mathrm{O}_{5}-\mathrm{SiO}_{2}-$ $\mathrm{K}_{2} \mathrm{O}-\mathrm{MgO}-\mathrm{CaO}-\mathrm{Fe}_{2} \mathrm{O}_{3}$ system $(\mathrm{mol} \%)$

\begin{tabular}{llllllll}
\hline No. & $\mathrm{SiO}_{2}$ & $\mathrm{P}_{2} \mathrm{O}_{5}$ & $\mathrm{~K}_{2} \mathrm{O}$ & $\mathrm{MgO}$ & $\mathrm{CaO}$ & $\mathrm{Fe}_{2} \mathrm{O}_{3}$ & Amorphous/crystalline \\
\hline $2 \mathrm{Fe} 41 \mathrm{P}$ & 6.0 & 41.0 & 6.0 & 27.0 & 18.0 & 2.0 & $\mathrm{~A}$ \\
$4 \mathrm{Fe} 41 \mathrm{P}$ & 6.0 & 41.0 & 6.0 & 25.8 & 17.2 & 4.0 & $\mathrm{~A}$ \\
$8 \mathrm{Fe} 41 \mathrm{P}$ & 6.0 & 41.0 & 6.0 & 23.4 & 15.6 & 8.0 & $\mathrm{~A}$ \\
$15 \mathrm{Fe} 41 \mathrm{P}$ & 6.0 & 41.0 & 6.0 & 19.2 & 12.8 & 15.0 & $\mathrm{~A}$ \\
$20 \mathrm{Fe} 41 \mathrm{P}$ & 6.0 & 41.0 & 6.0 & 16.2 & 10.8 & 20.0 & $\mathrm{~A}$ \\
$25 \mathrm{Fe} 41 \mathrm{P}$ & 6.0 & 41.0 & 6.0 & 13.2 & 8.8 & 25.0 & $\mathrm{~A}$ \\
$30 \mathrm{Fe} 41 \mathrm{P}$ & 6.0 & 41.0 & 6.0 & 10.2 & 6.8 & 30.0 & $\mathrm{~A}$ \\
$32 \mathrm{Fe} 41 \mathrm{P}$ & 6.0 & 41.0 & 6.0 & 9.0 & 6.0 & 32.0 & $\mathrm{~A}$ \\
$33 \mathrm{Fe} 41 \mathrm{P}$ & 6.0 & 41.0 & 6.0 & 8.4 & 5.6 & 33.0 & $\mathrm{~A}$ \\
$34 \mathrm{Fe} 41 \mathrm{P}$ & 6.0 & 41.0 & 6.0 & 7.8 & 5.2 & 34.0 & $\mathrm{C}$ \\
$40 \mathrm{Fe} 41 \mathrm{P}$ & 6.0 & 41.0 & 6.0 & 4.2 & 2.8 & 40.0 & $\mathrm{C}$ \\
$45 \mathrm{Fe} 41 \mathrm{P}$ & 6.0 & 41.0 & 6.0 & 1.2 & 0.8 & 45.0 & $\mathrm{C}$ \\
$47 \mathrm{Fe} 41 \mathrm{P}$ & 6.0 & 41.0 & 6.0 & - & - & 47.0 & $\mathrm{C}$ \\
\hline A & 6.0 & & & &
\end{tabular}

$A$ fully amorphous, $C$ glass-crystalline material 
data were designated by applying the Netzsch Proteus Thermal Analysis Program (version 5.0.0.).

The fraction containing the particle size of $0.1-0.3 \mathrm{~mm}$ was separated for selected glasses and glass-crystalline materials in order to proceed with the isothermal heating for $12 \mathrm{~h}$ at the crystallization temperatures designated from the DSC measurements. Crystalline products were identified by XRD method.

Phase composition of the devitrificates obtained from selected samples was designated by X-ray diffraction analysis (X'Pert Pro, Empyrean, Panalytical), and the Rietveld refinement was used to determine quantitative phase content. The internal standard method $\left(\mathrm{Al}_{2} \mathrm{O}_{3}\right)$ was used to evaluate the content of the amorphous phase in studied glass-crystalline materials.

The FEI Nova NanoSEM 200 scanning electron microscope was used to perform SEM-EDS observations of the investigated materials. The observations were conducted in high vacuum conditions, with backscatter electron detector (BSED); the accelerated voltage was $18 \mathrm{kV}$.

\section{Analysis of iron phosphate-silicate glass material and the evaluation of glass formation in studied system}

Results of XRD analysis imply the $33 \mathrm{~mol} \%$ and 0.83 to be the limit values of iron (III) oxide addition and associated $\mathrm{Fe} /(\mathrm{Fe}+\mathrm{Ca}+\mathrm{Mg})$ ratio of the fully amorphous material with the highest amount of incorporated $\mathrm{Fe}_{2} \mathrm{O}_{3}$ (Fig. 1). The further addition of $\mathrm{Fe}_{2} \mathrm{O}_{3}$ leads to the formation of glass-crystalline materials.

The SEM-EDS analysis performed on the selected samples with decreased level of amorphousness allowed to detect the regions characterized by different chemical composition (Fig. 2). The thermal characteristic was carried out in the wide range of the chemical composition-not only the fully amorphous samples were analyzed but also the selected one with iron (III) oxide addition exceeded $33 \mathrm{~mol} \%$ (Fig. 3).

The results of DSC analysis indicate that the analyzed heated-up iron phosphate-silicate glasses, modified with the addition of $\mathrm{Fe}_{2} \mathrm{O}_{3}$ (from 2 to $47 \mathrm{~mol} \%$ ), undergo the thermodynamic transformation characteristic for glasses, i.e., glass transition, crystallization and melting. The effect of chemical composition on the selected thermal parameters is shown in Fig. 3 and summarized in Table 2.

As can be seen in DSC curves (Fig. 3), glass transition effect is pronounced in samples up to $45 \mathrm{~mol} \% \mathrm{Fe}_{2} \mathrm{O}_{3}$ addition and parallelly confirms the presence of glassy phase in glass-crystalline materials containing magnesium and calcium ions, independently from the rate of iron (III) oxide incorporation. Concomitantly, results of the X-ray diffraction analysis carried for $40 \mathrm{Fe} 41 \mathrm{P}$ and $45 \mathrm{Fe} 41 \mathrm{P}$ corroborate that the gradual $\mathrm{Fe}_{2} \mathrm{O}_{3}$ addition is combined with the increase in the level of crystallinity. Particularly, the associated amount of amorphous phase is $81.5 \%$ $(40 \mathrm{Fe} 41 \mathrm{P})$ and $78.4 \%(45 \mathrm{Fe} 41 \mathrm{P})$. Thus, it is postulated that materials from $\mathrm{P}_{2} \mathrm{O}_{5}-\mathrm{SiO}_{2}-\mathrm{K}_{2} \mathrm{O}-\mathrm{MgO}-\mathrm{CaO}-\mathrm{Fe}_{2} \mathrm{O}_{3}$ system with previously exemplified correlations between the content of particular oxides, are characterized by significant amorphous phase-forming ability.

The $45 \mathrm{Fe} 41 \mathrm{P}$ is the glass-crystalline material in the analyzed series characterized by the highest incorporation of $\mathrm{Fe}_{2} \mathrm{O}_{3}$ with minor content of magnesium and calcium ions in the structure. Collected X-ray diffraction data were considered to be sufficient for qualitative and quantitative determination of crystalline phases. Therefore, the analysis was carried out without inducing the crystallization process through isothermal heating, which was required for 40Fe41P.
Fig. 1 X-ray diffraction image associated with the verification of amorphous state of selected samples from $\mathrm{P}_{2} \mathrm{O}_{5}-\mathrm{SiO}_{2}-\mathrm{K}_{2} \mathrm{O}-$ $\mathrm{MgO}-\mathrm{CaO}-\mathrm{Fe}_{2} \mathrm{O}_{3}$ system

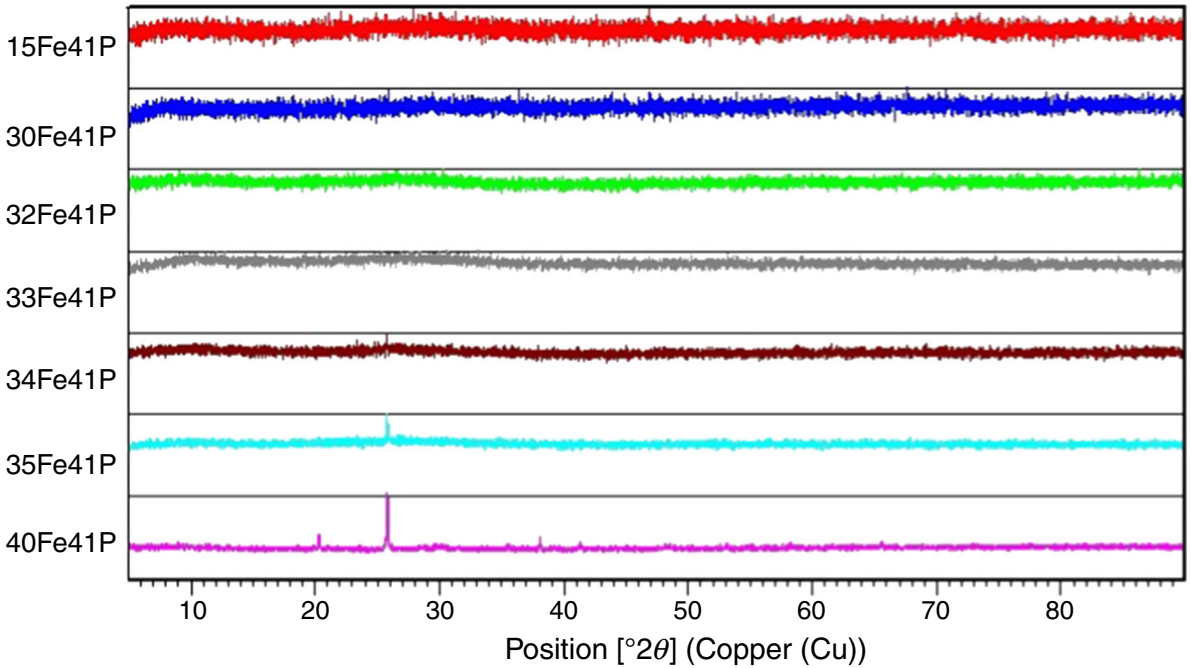


Fig. 2 a SEM-EDS

microphotographs of 40Fe41P sample. b SEM-EDS

microphotographs of $45 \mathrm{Fe} 41 \mathrm{P}$ sample
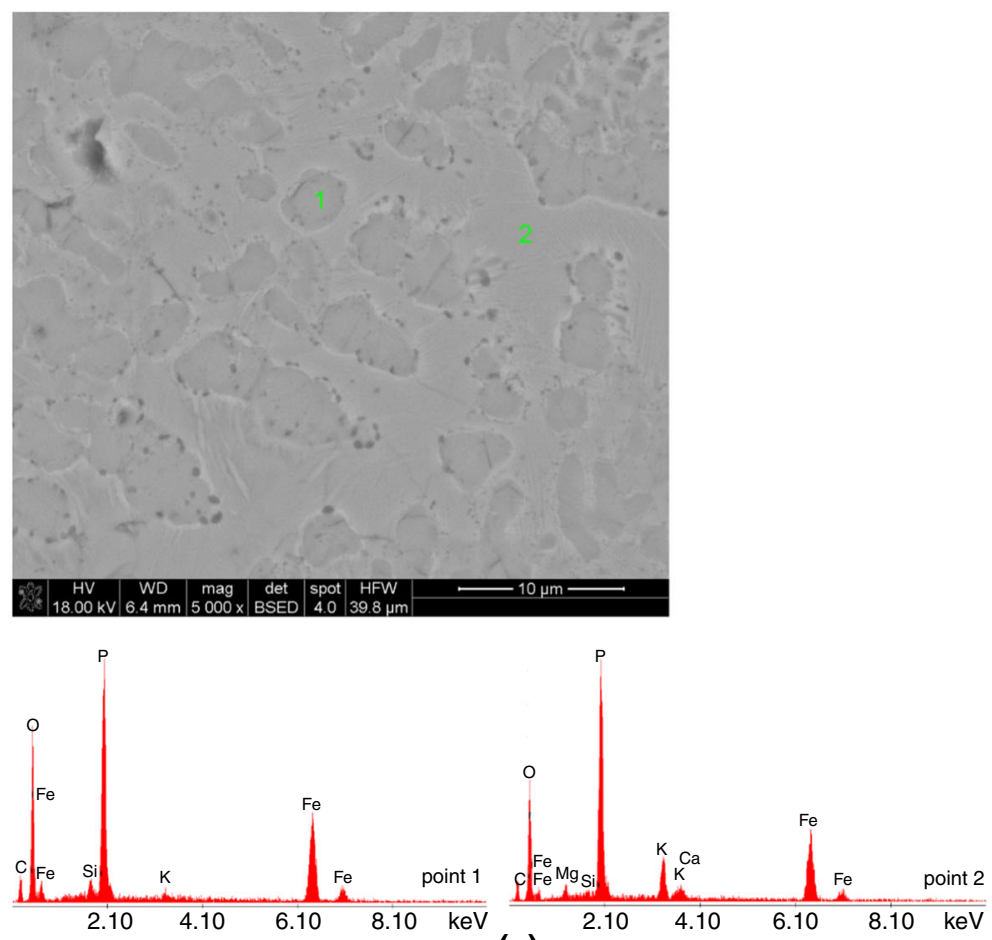

(a)
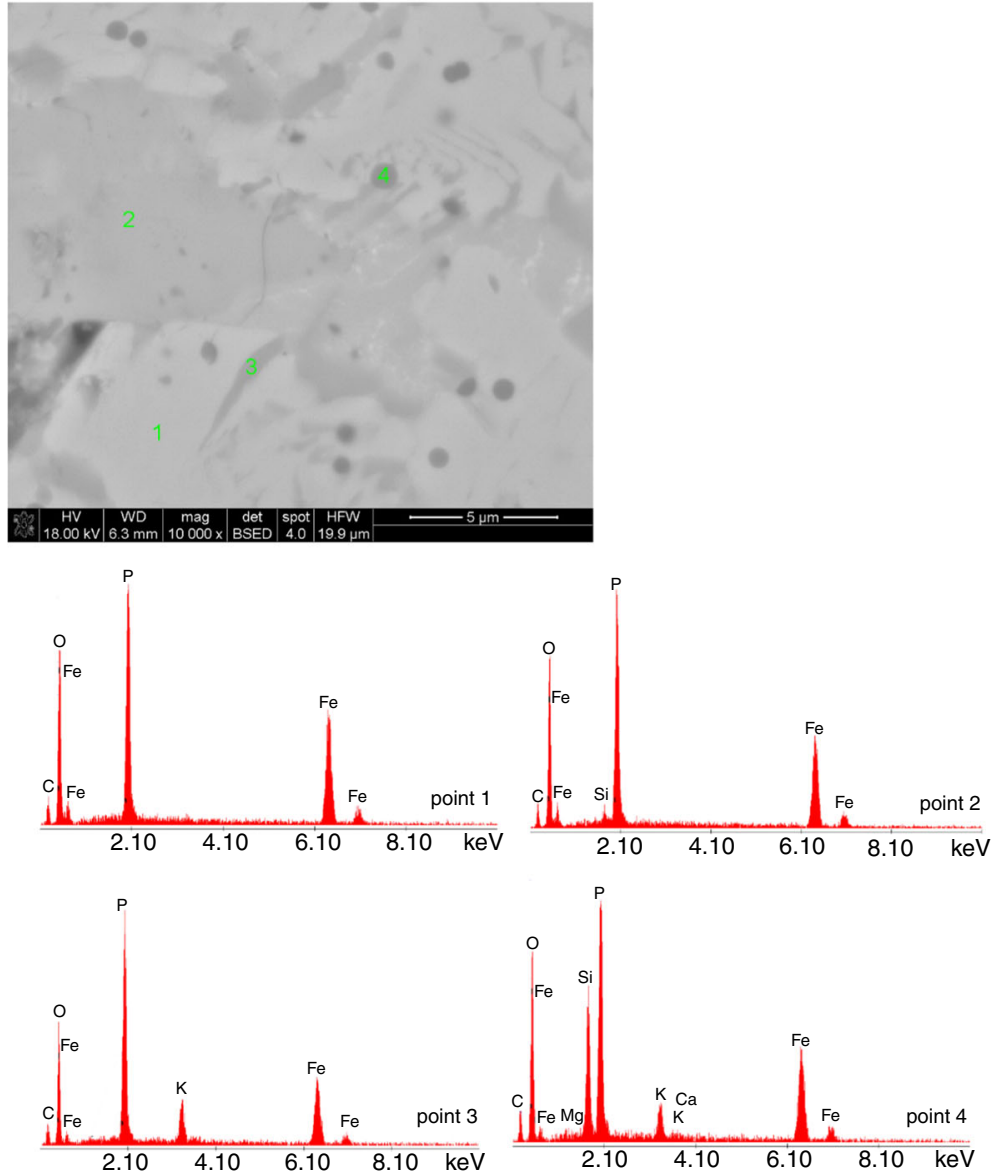

(b) 


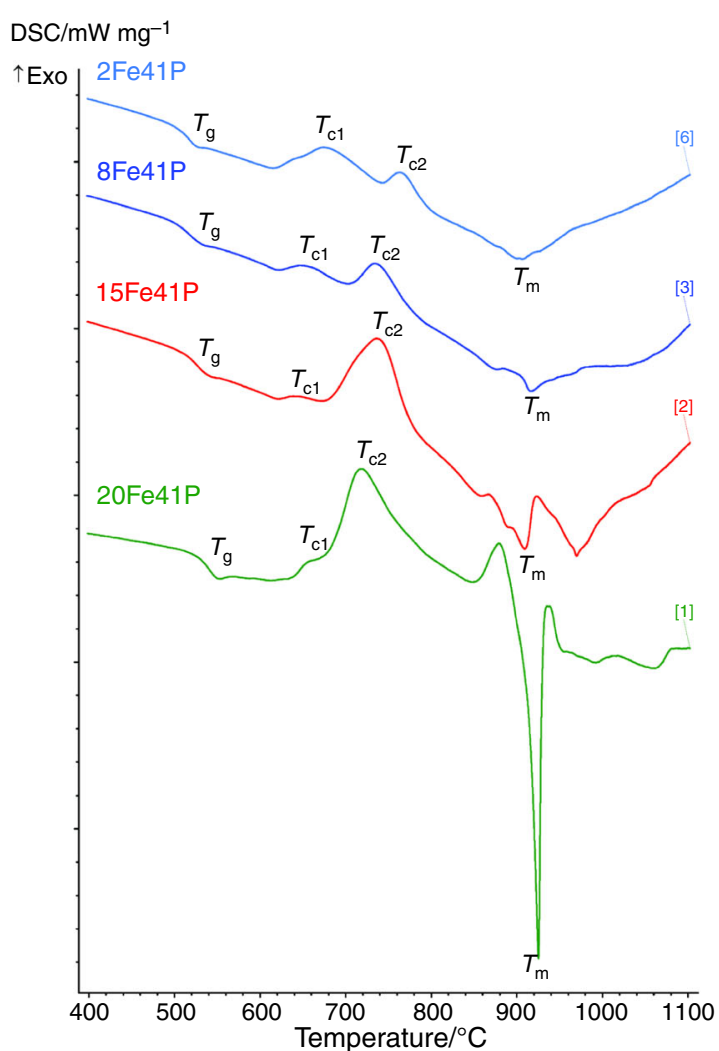

(a)
$\mathrm{DSC} / \mathrm{mW} \mathrm{mg}^{-1}$

$\uparrow$ Exo .

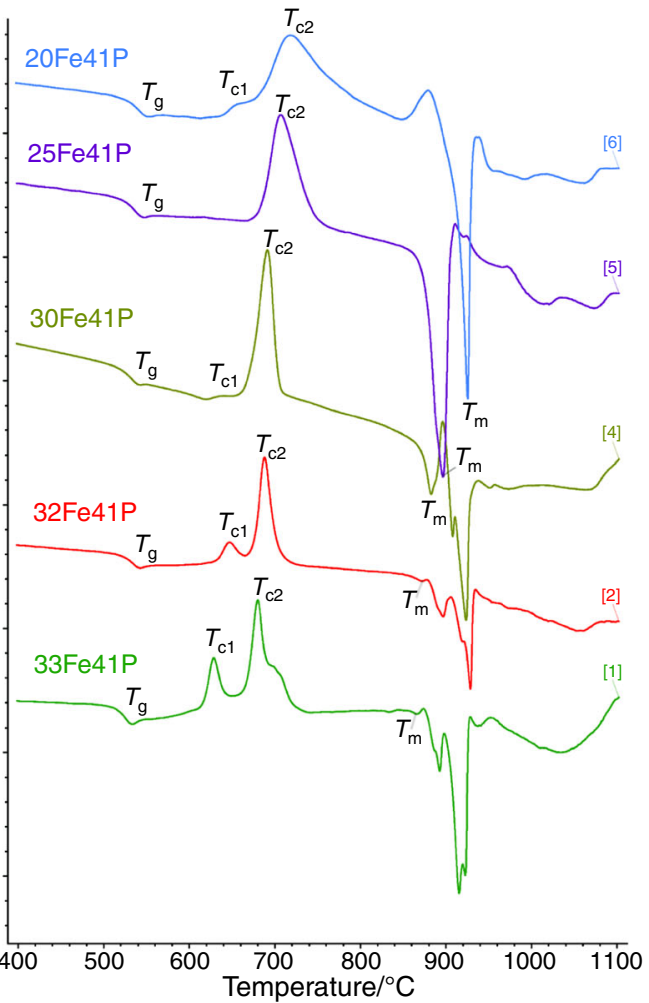

(b)

$\mathrm{DSC} / \mathrm{mW} \mathrm{mg}^{-1}$

$\uparrow$ Exo

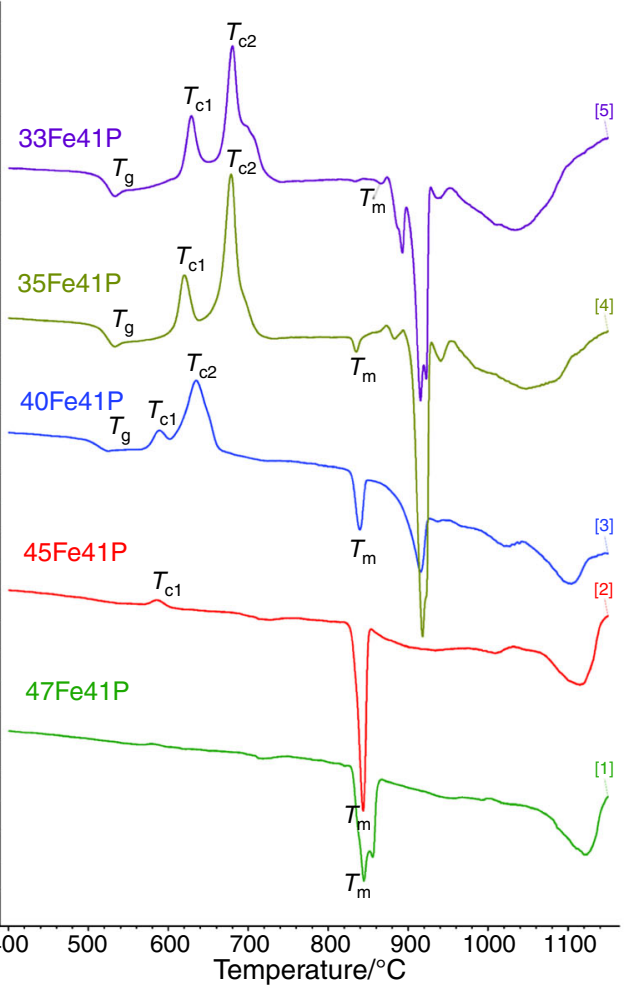

(c)

Fig. 3 DSC curves of analyzed glasses and glass-crystalline materials 
Table 2 A summary of characteristic parameters designated from obtained DSC curves, calculated thermal stability parameters and parameters calculated from the chemical composition of the iron phosphate-silicate glasses and glass-crystalline materials

\begin{tabular}{llllllll}
\hline & $2 \mathrm{Fe} 41 \mathrm{P}$ & $4 \mathrm{Fe} 41 \mathrm{P}$ & $8 \mathrm{Fe} 41 \mathrm{P}$ & $15 \mathrm{Fe} 41 \mathrm{P}$ & $20 \mathrm{Fe} 41 \mathrm{P}$ & $25 \mathrm{Fe} 41 \mathrm{P}$ & $30 \mathrm{Fe} 41 \mathrm{P}$ \\
\hline $\mathrm{O} / \mathrm{P} /-$ & 3.3 & 3.4 & 3.5 & 3.7 & 3.8 & 3.9 & 4.0 \\
$\mathrm{Fe} /(\mathrm{Fe}+\mathrm{Ca}+\mathrm{Mg}) /-$ & 0.08 & 0.16 & 0.29 & 0.48 & 0.60 & 0.69 & 0.78 \\
$T_{\mathrm{g}} /{ }^{\circ} \mathrm{C}$ & 512 & 512 & 514 & 524 & 537 & 532 & 528 \\
$T_{\mathrm{c} 1} /{ }^{\circ} \mathrm{C}$ & 675 & 651 & 646 & 639 & 653 & 707 & 642 \\
$T_{\mathrm{c} 2} /{ }^{\circ} \mathrm{C}$ & 763 & 739 & 735 & 737 & 718 & - & 691 \\
$\mathrm{~T}_{\mathrm{m}} /{ }^{\circ} \mathrm{C}$ & 907 & 872 & 916 & 909 & 925 & 897 & 883 \\
$\Delta T /{ }^{\circ} \mathrm{C}$ & 163 & 139 & 132 & 115 & 116 & 175 & 114 \\
$K_{\mathrm{W}} /-$ & 0.18 & 0.16 & 0.14 & 0.13 & 0.13 & 0.20 & 0.13 \\
\hline & $32 \mathrm{Fe} 41 \mathrm{P}$ & $33 \mathrm{Fe} 41 \mathrm{P}$ & $35 \mathrm{Fe} 41 \mathrm{P}$ & $40 \mathrm{Fe} 41 \mathrm{P}$ & $45 \mathrm{Fe} 41 \mathrm{P}$ & $47 \mathrm{Fe} 41 \mathrm{P}$ \\
\hline $\mathrm{O} / \mathrm{P} /-$ & 4.1 & 4.1 & 4.1 & 4.3 & 4.4 & 4.4 \\
$\mathrm{Fe} /(\mathrm{Fe}+\mathrm{Ca}+\mathrm{Mg}) /-$ & 0.81 & 0.83 & 0.85 & 0.92 & 0.98 & 1.0 \\
$T_{\mathrm{g}} /{ }^{\circ} \mathrm{C}$ & 529 & 522 & 521 & 513 & - & - \\
$T_{\mathrm{c} 1} /{ }^{\circ} \mathrm{C}$ & 647 & 629 & 619 & 589 & 586 & 581 \\
$T_{\mathrm{c} 2} /{ }^{\circ} \mathrm{C}$ & 688 & 680 & 679 & 635 & - & - \\
$\mathrm{Tm} /{ }^{\circ} \mathrm{C}$ & 874 & 866 & 835 & 839 & 844 & 844 \\
$\Delta T /{ }^{\circ} \mathrm{C}$ & 118 & 107 & 98 & 76 & & \\
$K_{\mathrm{W}} /-$ & 0.14 & 0.12 & 0.12 & 0.09 & &
\end{tabular}

40Fe41P and 45Fe41P glass-crystalline materials exhibit the presence of three distinctive phases, such as $\mathrm{FePO}_{4}$, $\mathrm{FeKP}_{2} \mathrm{O}_{7}$ and $\mathrm{Fe}_{7}\left(\mathrm{PO}_{4}\right)_{6}$. The Rietveld analysis performed for $40 \mathrm{Fe} 41 \mathrm{P}$ revealed that the content of each products is influenced by the heating temperature (Table 3). Concomitantly, the corresponding amount of particular phases designated for $45 \mathrm{Fe} 41 \mathrm{P}$ is varied. Particularly, the fraction of $\mathrm{Fe}_{7}\left(\mathrm{PO}_{4}\right)_{6}$ is increased to $42.5 \%$, content of $\mathrm{FePO}_{4}$ is relatively less influenced $(38.3 \%)$, and $\mathrm{FeKP}_{2} \mathrm{O}_{7}$ is reduced to $19.2 \%$.

In the microphotographs of the samples obtained by SEM-EDS (Fig. 2), regions rich in phosphorus and iron, and also with phosphorus, iron and potassium, were featured. It supports the acquired data correlated with crystallization of $\mathrm{FeKP}_{2} \mathrm{O}_{7}, \mathrm{Fe}_{7}\left(\mathrm{PO}_{4}\right)_{6}$ and $\mathrm{FePO}_{4}$ phases and confirms that mentioned elements tend to be incorporated into crystalline products to a considerable degree compared to magnesium, silicon and calcium.

Additionally, the relatively small area enriched with silicon is found. The minor concentrations of magnesium and calcium are also detected. Considering the results of qualitative analysis of crystalline products carried out by $\mathrm{X}$-ray diffraction method, it can be postulated that silicon, magnesium and calcium are more likely originated from the amorphous phase, which is present in the sample in a significant amount $(81.5 \%$ for $40 \mathrm{Fe} 41 \mathrm{P}$ and $78.4 \%$ for $45 \mathrm{Fe} 41 \mathrm{P})$. It can be explained through the evaluation of ionicity of the chemical bonds (" $i_{\mathrm{G}}$ ") and the binding electron location parameter (" $L$ ") which are measures of the elasticity of the vitreous bond and the rigidity of chemical bonds, respectively [20].

Analysis of ionicity values of chemical bonds for $\mathrm{P}-\mathrm{O}$ $\left(i_{\mathrm{G}} \mathrm{P}-\mathrm{O}=0.314 ; L=2.640\right)$ and $\mathrm{Si}-\mathrm{O}\left(i_{\mathrm{G}} \quad \mathrm{Si}-\mathrm{O}=0.428\right.$; $L=2.410$ ) [20] clearly indicates that lower value of elasticity of bonds will result in greater tendency to the destruction of the glass structure. Therefore, the silicate network is stronger and requires higher energy to be destroyed which contributes to the impediment of the crystallization of silicates [21]. Thus, only the crystallization of phosphates is observed.

\section{Analysis of iron phosphate-silicate glasses and glass-crystalline materials after the induced crystallization process}

The multistage crystallization of glasses from $\mathrm{P}_{2} \mathrm{O}_{5}-\mathrm{SiO}_{2}-$ $\mathrm{K}_{2} \mathrm{O}-\mathrm{MgO}-\mathrm{CaO}-\mathrm{Fe}_{2} \mathrm{O}_{3}$ system exhibits exothermic, partially overlapped effects $\left(T_{\mathrm{c} 1}\right.$ and $\left.T_{\mathrm{c} 2}\right)$ exposed in associated DSC curves (Fig. 3a-c). The course of the process in analyzed multicomponent system is influenced by a wide range of factors such as physicochemical factors, chemical affinity, the assumptions about the rate of magnesium and calcium ions substitution $(\mathrm{Fe} /(\mathrm{Fe}+\mathrm{Ca}+\mathrm{Mg}))$ and even the fractions of di- and trivalent iron ions. In order to explain the progressive alterations occurring with gradual $\mathrm{Fe}_{2} \mathrm{O}_{3}$ incorporation at the expense of $\mathrm{MgO}$ and $\mathrm{CaO}$, the corresponding crystalline products were assigned via XRD. 
Table 3 The kind of crystallizing phases identified in the analyzed devitrificates

\begin{tabular}{|c|c|c|c|c|c|c|c|c|}
\hline & $4 \mathrm{Fe} 41 \mathrm{P}$ & $8 \mathrm{Fe} 41 \mathrm{P}$ & $15 \mathrm{Fe} 41 \mathrm{P}$ & $25 \mathrm{Fe} 41 \mathrm{P}$ & $30 F e 41 P$ & $32 \mathrm{Fe} 41 \mathrm{P}$ & $35 \mathrm{Fe} 41 \mathrm{P}$ & $40 \mathrm{Fe} 41 \mathrm{P}$ \\
\hline \multicolumn{9}{|l|}{$T_{\mathrm{c} 1}$} \\
\hline Phase 1 & $\mathrm{KMg}\left(\mathrm{PO}_{3}\right)_{3}$ & $\mathrm{FeKP}_{2} \mathrm{O}_{7}$ & $\mathrm{FeKP}_{2} \mathrm{O}_{7}$ & - & Un & $\mathrm{FeKP}_{2} \mathrm{O}_{7}$ & $\mathrm{FeKP}_{2} \mathrm{O}_{7}$ & $\mathrm{FeKP}_{2} \mathrm{O}_{7}$ \\
\hline Ref. code & $\begin{array}{l}\text { IGOD } \\
01-074- \\
2002\end{array}$ & $\begin{array}{l}\text { ICSD } \\
98-020- \\
2814\end{array}$ & $\begin{array}{l}\text { ICSD } \\
98-008- \\
6309\end{array}$ & - & - & $\begin{array}{l}\text { ICSD } \\
98-020- \\
2814\end{array}$ & $\begin{array}{l}\text { ICSD } \\
98-020- \\
2814\end{array}$ & $\begin{array}{l}\text { ICSD } \\
98-020- \\
2814\end{array}$ \\
\hline Fraction/\% & - & - & - & - & - & 46.7 & 31.1 & 25.1 \\
\hline $\begin{array}{l}\text { Free enthalpy/ } \\
\mathrm{kJ} \mathrm{mol}^{-1}\end{array}$ & -5820.86 & -4009.50 & -4009.50 & - & - & -4009.50 & -4009.50 & -4009.50 \\
\hline Phase 2 & $\mathrm{CaMgP}_{2} \mathrm{O}_{7}$ & $\mathrm{CaMgP}_{2} \mathrm{O}_{7}$ & - & - & Un & $\mathrm{FePO}_{4}$ & $\mathrm{FePO}_{4}$ & $\mathrm{FePO}_{4}$ \\
\hline Ref. code & $\begin{array}{l}\text { IGOD } \\
\text { 00-024- } \\
0135\end{array}$ & $\begin{array}{l}\text { IGOD } \\
00-024- \\
0135\end{array}$ & - & - & - & $\begin{array}{l}\text { ICSD } \\
98-041- \\
2737\end{array}$ & $\begin{array}{l}\text { ICSD } \\
98-041- \\
2742\end{array}$ & $\begin{array}{l}\text { ICSD } \\
98-041- \\
2742\end{array}$ \\
\hline Fraction/\% & - & - & - & - & - & 53.3 & 47.6 & 40.9 \\
\hline $\begin{array}{l}\text { Free enthalpy/ } \\
\mathrm{kJ} \mathrm{mol}^{-1}\end{array}$ & -4622.33 & -4622.33 & - & - & - & -2122.18 & -2122.18 & -2122.18 \\
\hline Phase 3 & - & - & - & - & - & - & $\mathrm{Fe}_{7}\left(\mathrm{PO}_{4}\right)_{6}$ & $\mathrm{Fe}_{7}\left(\mathrm{PO}_{4}\right)_{6}$ \\
\hline Ref. code & - & - & - & - & - & - & $\begin{array}{l}\text { ICSD } \\
\text { 98-002- } \\
0765\end{array}$ & $\begin{array}{l}\text { ICSD } \\
\text { 98-002- } \\
0765\end{array}$ \\
\hline Fraction/\% & - & - & - & - & - & - & 21.3 & 34.0 \\
\hline $\begin{array}{l}\text { Free enthalpy/ } \\
\mathrm{kJ} \mathrm{mol}^{-1}\end{array}$ & - & - & - & - & - & - & $-13,080.5$ & $-13,080.5$ \\
\hline \multicolumn{9}{|l|}{$T_{\mathrm{c} 2}$} \\
\hline $\begin{array}{l}\text { Phase } 1 \\
\text { Ref. code }\end{array}$ & $\begin{array}{l}\mathrm{Mg}_{2}\left(\mathrm{PO}_{3}\right)_{4} \\
\mathrm{ICSD} \\
98-000- \\
4280\end{array}$ & $\begin{array}{l}\mathrm{FeKP}_{2} \mathrm{O}_{7} \\
\mathrm{ICSD} \\
98-020- \\
2814\end{array}$ & $\begin{array}{l}\mathrm{FeKP}_{2} \mathrm{O}_{7} \\
\mathrm{ICSD} \\
98-008- \\
6309\end{array}$ & $\begin{array}{l}\mathrm{FeKP}_{2} \mathrm{O}_{7} \\
\mathrm{ICSD} \\
98-009- \\
6309\end{array}$ & $\begin{array}{l}\mathrm{FeKP}_{2} \mathrm{O}_{7} \\
\mathrm{IGOD} \\
01-084- \\
1798\end{array}$ & $\begin{array}{l}\mathrm{FeKP}_{2} \mathrm{O}_{7} \\
\mathrm{ICSD} \\
98-020- \\
2814\end{array}$ & $\begin{array}{l}\mathrm{FeKP}_{2} \mathrm{O}_{7} \\
\mathrm{ICSD} \\
98-020- \\
2814\end{array}$ & $\begin{array}{l}\mathrm{FeKP}_{2} \mathrm{O}_{7} \\
\mathrm{ICSD} \\
98-020- \\
2814\end{array}$ \\
\hline Fraction/\% & & & & & 51.8 & 53.4 & 33.6 & 25.0 \\
\hline $\begin{array}{l}\text { Free enthalpy/ } \\
\mathrm{kJ} \mathrm{mol}^{-1}\end{array}$ & -8023.05 & -4101.97 & -4101.97 & -4101.97 & -4101.97 & -4101.97 & -4101.97 & -4009.50 \\
\hline Phase 2 & $\mathrm{CaMgP}_{2} \mathrm{O}_{7}$ & $\mathrm{CaMgP}_{2} \mathrm{O}_{7}$ & $\mathrm{CaMgP}_{2} \mathrm{O}_{7}$ & $\mathrm{Fe}_{3}\left(\mathrm{PO}_{4}\right)_{2}$ & $\mathrm{FePO}_{4}$ & $\mathrm{FePO}_{4}$ & $\mathrm{FePO}_{4}$ & $\mathrm{FePO}_{4}$ \\
\hline Ref. code & $\begin{array}{l}\text { IGOD } \\
\text { 00-024- } \\
0135\end{array}$ & $\begin{array}{l}\text { IGOD } \\
\text { 00-024- } \\
0135\end{array}$ & $\begin{array}{l}\text { IGOD } \\
00-024- \\
0135\end{array}$ & $98-028-1704$ & $\begin{array}{l}\text { IGOD } \\
01-070- \\
1793\end{array}$ & $\begin{array}{l}\text { ICSD } \\
98-041- \\
2737\end{array}$ & $\begin{array}{l}\text { ICSD } \\
98-041- \\
2742\end{array}$ & $\begin{array}{l}\text { ICSD } \\
98-041- \\
2742\end{array}$ \\
\hline Fraction/\% & & & & & 48.2 & 46.6 & 35.2 & 36.8 \\
\hline $\begin{array}{l}\text { Free enthalpy/ } \\
\mathrm{kJ} \mathrm{mol}^{-1}\end{array}$ & -4709.98 & -4709.98 & -4709.98 & -4333.25 & -2169.40 & -2169.40 & -2169.40 & -2122.18 \\
\hline Phase 3 & - & - & - & - & - & - & $\mathrm{Fe}_{7}\left(\mathrm{PO}_{4}\right)_{6}$ & $\mathrm{Fe}_{7}\left(\mathrm{PO}_{4}\right)_{6}$ \\
\hline Ref. code & - & - & - & - & - & - & $\begin{array}{l}\text { ICSD } \\
\text { 98-002- } \\
0765\end{array}$ & $\begin{array}{l}\text { ICSD } \\
\text { 98-002- } \\
0765\end{array}$ \\
\hline Fraction/\% & - & - & - & - & - & - & 31.2 & 38.2 \\
\hline $\begin{array}{l}\text { Free enthalpy/ } \\
\mathrm{kJ} \mathrm{mol}^{-1}\end{array}$ & - & - & - & - & - & - & $-13,376.2$ & $-13,080.5$ \\
\hline
\end{tabular}

Un unidentified 
Results of performed spectroscopic analysis conducted on $\mathrm{P}_{2} \mathrm{O}_{5}-\mathrm{SiO}_{2}-\mathrm{K}_{2} \mathrm{O}-\mathrm{MgO}-\mathrm{CaO}-\mathrm{Fe}_{2} \mathrm{O}_{3}$ glasses have provided interesting data about the structure of analyzed materials [19]. The main conclusion is that $\mathrm{Fe}_{2} \mathrm{O}_{3}$ addition leads to the progressive depolymerization of the phosphorus subnetwork and increase in the content of ferric ions both tetrahedrally and octahedrally coordinated at the expense of ferrous ions. The rate of depolymerization degree is revealed by $\mathrm{O} / \mathrm{P}$ ratio which also suggests the kind of prevailing phosphate units [22]. The alterations in chemical composition are reflected through individual parameter, similarly as in [23]. Due to the fact that iron (III) oxide is incorporated at the expense of $\mathrm{MgO}$ and $\mathrm{CaO}$, it was decided to present the nominal changes via $\mathrm{Fe} /$ $(\mathrm{Fe}+\mathrm{Ca}+\mathrm{Mg})$ ratio which decreases with the increase in content of calcium and magnesium ions. The limited value calculated from nominal chemical composition of glass containing the comparable amount of iron oxide and magnesium and calcium oxide (17.6 mol\% and $11.8 \mathrm{~mol} \%$, respectively) is set as 0.54 .

Results of Raman study [19] indicate that phosphorus subnetwork of glasses with lower iron (III) oxide addition not exceeded by $4 \mathrm{~mol} \%$ is built from metaphosphate units to a considerable degree. A distinctive spectra of 4Fe41P and $8 \mathrm{Fe} 41 \mathrm{P}$ implicate that $8 \mathrm{Fe} 41 \mathrm{P}$ is structurally more influenced through progressive discontinuity of the network and crucial role of pyrophosphate units. The structure undergoes a major transformation with further iron (III) oxide addition. Similarly as Raman spectra, DSC curves are gradually altered and it is combined with variation of products of the multistage crystallization (Fig. 3, Table 3).

As can be seen in Fig. 3a, multistage crystallization process exhibited by glasses with $\mathrm{Fe} /(\mathrm{Fe}+\mathrm{Ca}+\mathrm{Mg})$ ratio not exceeded 0.29 (marked as $2 \mathrm{Fe} 41 \mathrm{P}$ and $8 \mathrm{Fe} 41 \mathrm{P}$ ) proceeds in wider temperature range, especially compared to glasses with at least $30 \mathrm{~mol} \% \mathrm{Fe}_{2} \mathrm{O}_{3}$ addition (Fig. 3b, c).

Relatively small effects in wide temperature range presented in curves of glasses with lower iron (III) oxide addition, such as $2 \mathrm{Fe} 41 \mathrm{P}$ considered as highly polymerized, and $8 \mathrm{Fe} 41 \mathrm{P}$ are due to crystallization of phases enriched with links with greater ionicity $\left(i_{\mathrm{G} \mathrm{K}-\mathrm{O}}=0.823\right.$, $\left.i_{\mathrm{G} \mathrm{Ca-O}}=0.707, i_{\mathrm{G} \mathrm{Mg-O}}=0.670\right)$ such as $\mathrm{KMg}\left(\mathrm{PO}_{3}\right)_{3}$ and $\mathrm{CaMgP}_{2} \mathrm{O}_{7}\left(T_{\mathrm{c} 1}\right), \mathrm{Mg}_{2}\left(\mathrm{PO}_{3}\right)_{4}$ and $\mathrm{CaMgP}_{2} \mathrm{O}_{7}\left(T_{\mathrm{c} 2}\right)$ in $4 \mathrm{Fe} 41 \mathrm{P}$ (Fig. $4 \mathrm{a})$ and $\mathrm{CaMgP}_{2} \mathrm{O}_{7}\left(T_{\mathrm{c} 1}\right.$ and $\left.T_{\mathrm{c} 2}\right)$ in $8 \mathrm{Fe} 41 \mathrm{P}$ in which $\mathrm{FeK}\left(\mathrm{P}_{2} \mathrm{O}_{7}\right)$ was also found (Table 3).

The results of assignment presented in Table 3 also indicate that more polymerized phosphates were detected only in samples with a slight addition of $\mathrm{Fe}_{2} \mathrm{O}_{3}$ not exceeded $4 \mathrm{~mol} \%\left(\mathrm{KMg}\left(\mathrm{PO}_{3}\right)_{3}\right.$ and $\left.\mathrm{Mg}_{2} \mathrm{P}_{4} \mathrm{O}_{12}\right)$. It supports the conclusions of spectroscopic analysis. It is also presumable that due to the calculated values of $\Delta \mathrm{G}$, $\mathrm{KMg}\left(\mathrm{PO}_{3}\right)_{3}$ and $\mathrm{Mg}_{2}\left(\mathrm{PO}_{3}\right)_{4}$ are privileged in comparison with $\mathrm{CaMgP}_{2} \mathrm{O}_{7}$ (Table 3). Furthermore, bonds with more ionic character have superior elasticity and require more energy to be broken which is also reflected in the relatively wider range of crystallization temperatures exhibited in curve and also implies that the structure of glasses with lower iron (III) oxide addition is thermally strengthen.

Commencing from $15 \mathrm{Fe} 41 \mathrm{P}$ sample, the second exothermic peak is gaining on distinctiveness compared to the first effect. Simultaneously, the general tendency of crystallization temperatures to decrease and intensification of melting effects with the increase in $(\mathrm{Fe} /(\mathrm{Fe}+\mathrm{Ca}+$ $\mathrm{Mg})$ ) parameter is also presented.

It can be stated that the increase in distinctiveness of the second crystallization peak (Fig. 3) is probably combined with crystallization of iron-rich phosphate phases (Table 2) in which besides another possible joints, such as strongly ionic $\mathrm{K}-\mathrm{O}$ linkage in $\mathrm{FeKP}_{2} \mathrm{O}_{7}$, more covalent $\mathrm{Fe}^{3+}-\mathrm{O}$ bonds are marked. This is also the result of progressive decrease in magnesium and calcium ions content in the analyzed series of materials. The character of $\mathrm{Fe}^{3+}-\mathrm{O}$ links indicates the increased rigidity and it requires lower energy for its destruction. It also explains the general tendency to decrease the crystallization temperatures along with the increase in $\mathrm{Fe} /(\mathrm{Fe}+\mathrm{Ca}+\mathrm{Mg})$ parameter.

Additionally, the first crystallization effect is influenced. It may be deducted from Fig. 3a, b that it decreases and its assigned maximum temperature is altered which leads to the reduction in visible separateness and simultaneously results in emergence of the single peak at $707{ }^{\circ} \mathrm{C}(25 \mathrm{Fe} 41 \mathrm{P}$ curve). However, it is again revealed in $30 \mathrm{Fe} 41 \mathrm{P}$ curve, and from that point, it becomes to be more distinct.

Products assigned to the first visible crystallization effect also reflect the strong influence of chemical composition variations revealed by $\mathrm{Fe} /(\mathrm{Fe}+\mathrm{Ca}+\mathrm{Mg})$ ratio. As it was mentioned before, obtained phases associated with samples with iron (III) oxide addition not exceeded $4 \mathrm{~mol} \%$ are enriched with magnesium, potassium and calcium ions and possess a significant polymerization degree. Induced crystallization of $15 \mathrm{Fe} 41 \mathrm{P}$ and $20 \mathrm{Fe} 41 \mathrm{P}$ glasses leads to the formation of one phase named as iron potassium diphosphate (Table 3 ). The pronounced alteration is observed in $25 \mathrm{Fe} 41 \mathrm{P}$ curve. $25 \mathrm{Fe} 41 \mathrm{P}$ glass crystallization seems to be simplified and is displayed by single, less broaden peak in $707^{\circ} \mathrm{C}$ associated with $\mathrm{FeK}\left(\mathrm{P}_{2} \mathrm{O}_{7}\right)$ and $\mathrm{Fe}_{3}\left(\mathrm{PO}_{4}\right)_{2}$. The specific character of this curve needs to be explained by the key impact of $\mathrm{Fe}_{3}$ $\left(\mathrm{PO}_{4}\right)_{2}$, which apparently influences the crystallization of $\mathrm{FeKP}_{2} \mathrm{O}_{7}$ through increasing the temperature of the process. Thus, appearance of $\mathrm{Fe}_{3}\left(\mathrm{PO}_{4}\right)_{2}$ is directly connected to the exhibition of single presumably overlapped effect in the mentioned DSC curve.

The stoichiometry of the $\mathrm{Fe}_{3}\left(\mathrm{PO}_{4}\right)_{2}$ phase may be linked to the ferrous ions. It was concluded in [19] that the 

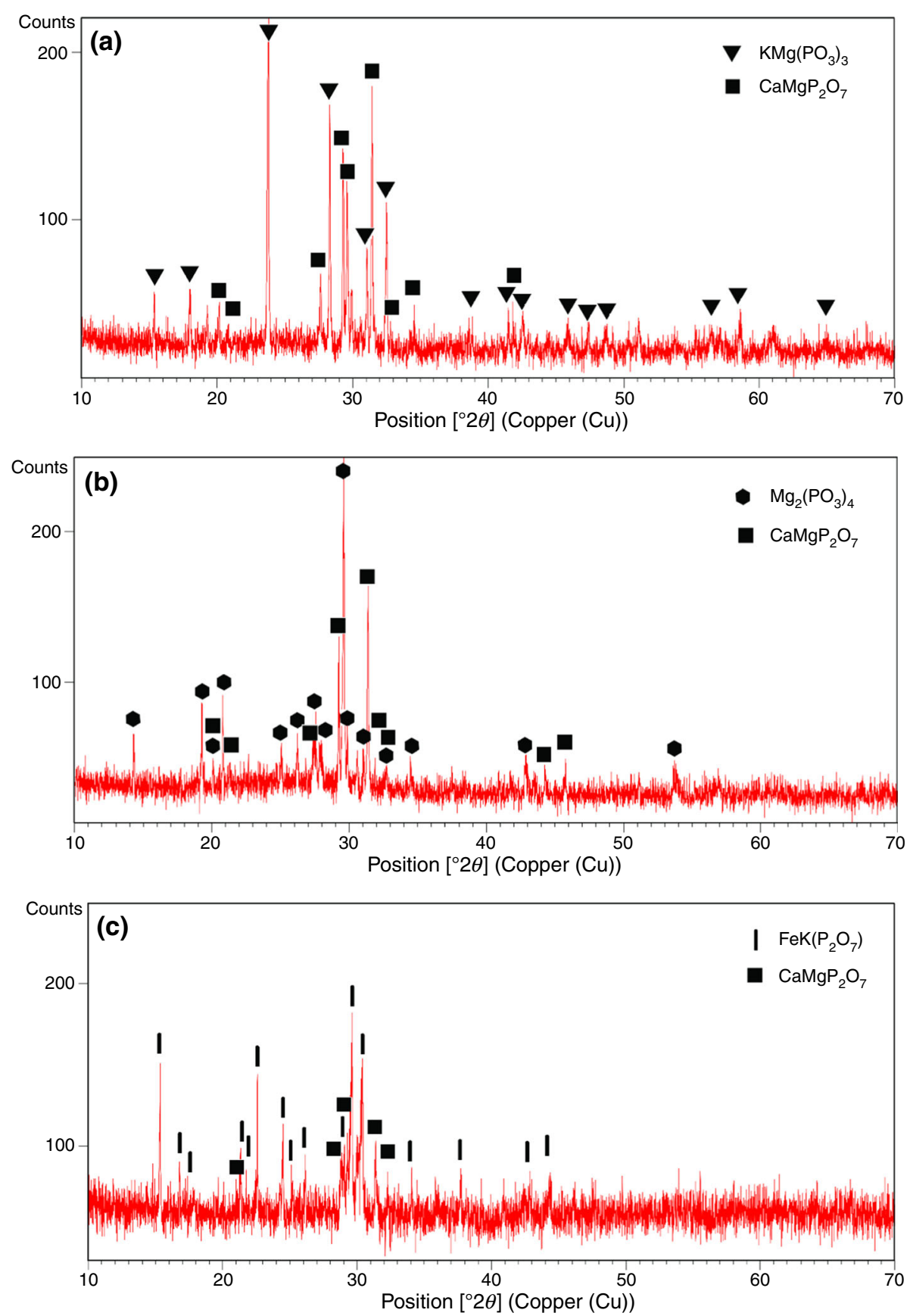

Fig. 4 XRD pattern and the assignment of crystalline phases conducted for a $4 \mathrm{Fe} 41 \mathrm{P}\left(T_{\mathrm{c} 1}\right), \mathbf{b} 4 \mathrm{Fe} 41 \mathrm{P}\left(T_{\mathrm{c} 2}\right), \mathbf{c} 15 \mathrm{Fe} 41 \mathrm{P}\left(T_{\mathrm{c} 2}\right), \mathbf{d} 25 \mathrm{Fe} 41 \mathrm{P}\left(T_{\mathrm{c} 2}\right)$ and $\mathbf{e} 30 \mathrm{Fe} 41 \mathrm{P}\left(T_{\mathrm{c} 2}\right)$ glasses subjected to the process of induced crystallization

increase in iron (III) oxide incorporation in analyzed system generally causes the increase in ferric ions at the expense of ferrous ions. Nevertheless, the presence of $\mathrm{Fe}^{2+}$ ions was confirmed for $30 \mathrm{Fe} 41 \mathrm{P}$ via Mössbauer spectroscopy. The appearance of $\mathrm{Fe}_{3}\left(\mathrm{PO}_{4}\right)_{2}$ needs to be explained by predominance of $\mathrm{Fe}_{2} \mathrm{O}_{3}(25 \mathrm{~mol} \%)$ over $\mathrm{MgO}$ $(13.2 \mathrm{~mol} \%)$ and $\mathrm{CaO}(8.8 \mathrm{~mol} \%)$ and the insufficient amount of magnesium and calcium ions for their incorporation into crystalline products.
The reappearance of the first effect $\left(T_{\mathrm{c} 1}\right)$ in $30 \mathrm{Fe} 41 \mathrm{P}$ curve and the alterations such as decrease in its assigned temperatures and distinctiveness visible in further curves up to $33 \mathrm{Fe} 41 \mathrm{P}$, are implied from the change of the type of crystallization products, particularly the vanishing of $\mathrm{Fe}_{3}\left(\mathrm{PO}_{4}\right)_{2}$ and appearance of $\mathrm{FePO}_{4}$. It could not have been reflected in experimental results collected from $30 \mathrm{Fe} 41 \mathrm{P}$ glass due to the proximity of the effects; however, it was succeeded for 32Fe41P sample (Table 3). 

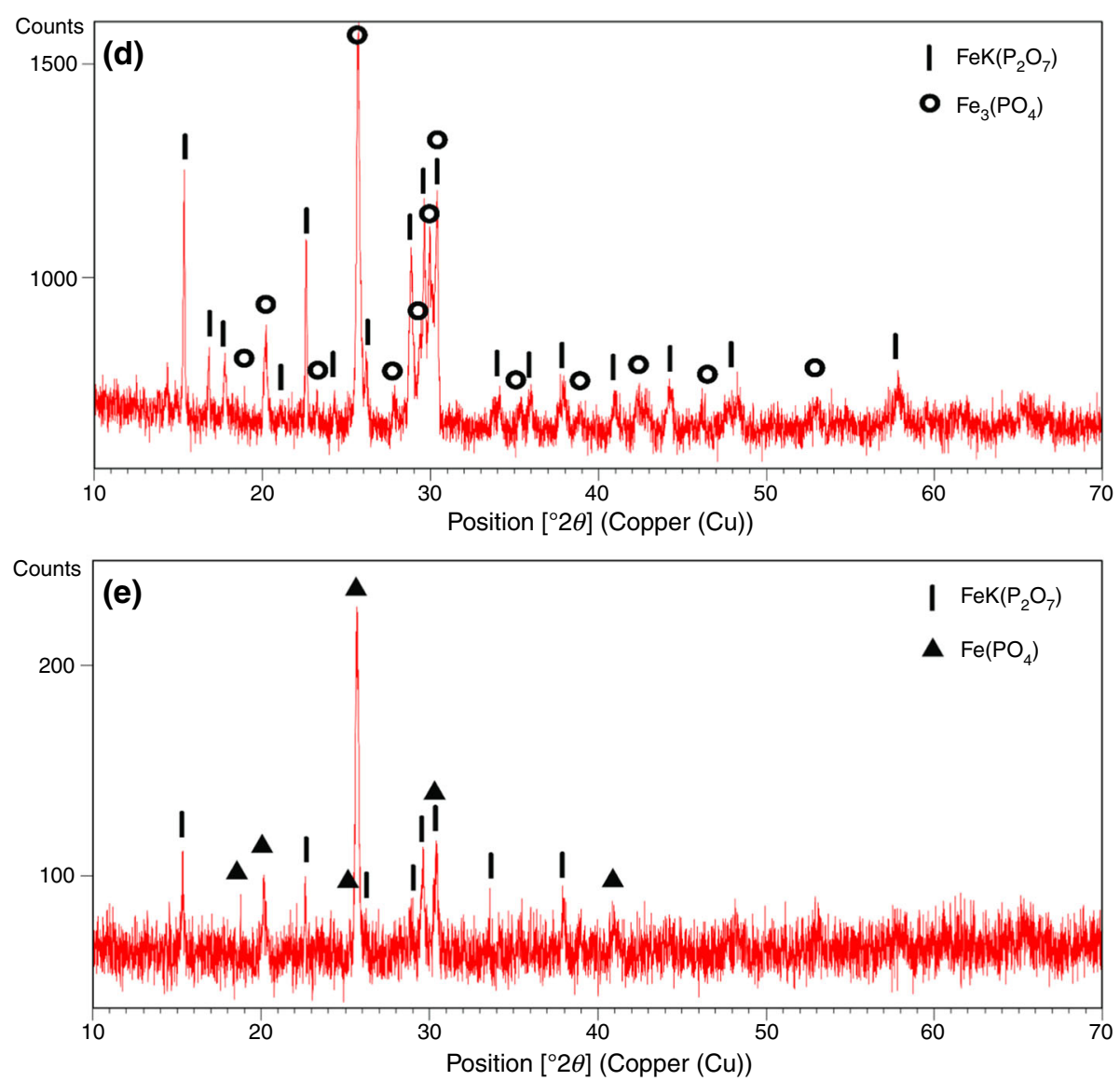

Fig. 4 continued

For further considerations, the Rietveld analysis was carried out for 30Fe41P, 32Fe41P, 35Fe41P and 40Fe41P samples subjected to the process of induced crystallization. Obtained results are presented in Fig. 5 and Table 3. Crystallization effects exhibited in curves of $30 \mathrm{Fe} 41 \mathrm{P}$ and $32 \mathrm{Fe} 41 \mathrm{P}$ glasses are associated with the presence of $\mathrm{FeKP}_{2} \mathrm{O}_{7}$ and $\mathrm{FePO}_{4}$. Further iron (III) oxide addition leads to the obtaining of glass-crystalline materials characterized also by the presence of $\mathrm{Fe}_{7}\left(\mathrm{PO}_{4}\right)_{6}$. The content of phases designated through Rietveld analysis varies depending on the $\mathrm{Fe} /(\mathrm{Fe}+\mathrm{Ca}+\mathrm{Mg})$ ratio and the temperature of combined exothermic effect.

The content of $\mathrm{FePO}_{4}$ is increased compared to $\mathrm{FeKP}_{2} \mathrm{O}_{7}$ in $30 \mathrm{Fe} 41 \mathrm{P}$ and $32 \mathrm{Fe} 41 \mathrm{P}$ samples in the second crystallization effect $\left(T_{\mathrm{c} 2}\right.$, Fig. 3$)$. The opposite results were obtained for the first crystallization effect $\left(T_{\mathrm{c} 1}\right)$. It may be presumed that crystallization of $\mathrm{FeKP}_{2} \mathrm{O}_{7}$ should be more associated with the second crystallization effect and in $T_{\mathrm{c} 1} \mathrm{FePO}_{4}$ is more privileged.

The occurrence of $\mathrm{Fe}_{7}\left(\mathrm{PO}_{4}\right)_{6}$ is attributed to the general decrease in amount of $\mathrm{FePO}_{4}$ and particularly $\mathrm{FeKP}_{2} \mathrm{O}_{7}$ in $T_{\mathrm{c} 2}$ (Fig. 5). Increasing content of $\mathrm{Fe}_{7}\left(\mathrm{PO}_{4}\right)_{6}$ at the expense of $\mathrm{FeKP}_{2} \mathrm{O}_{7}$ indicates the change in the type of

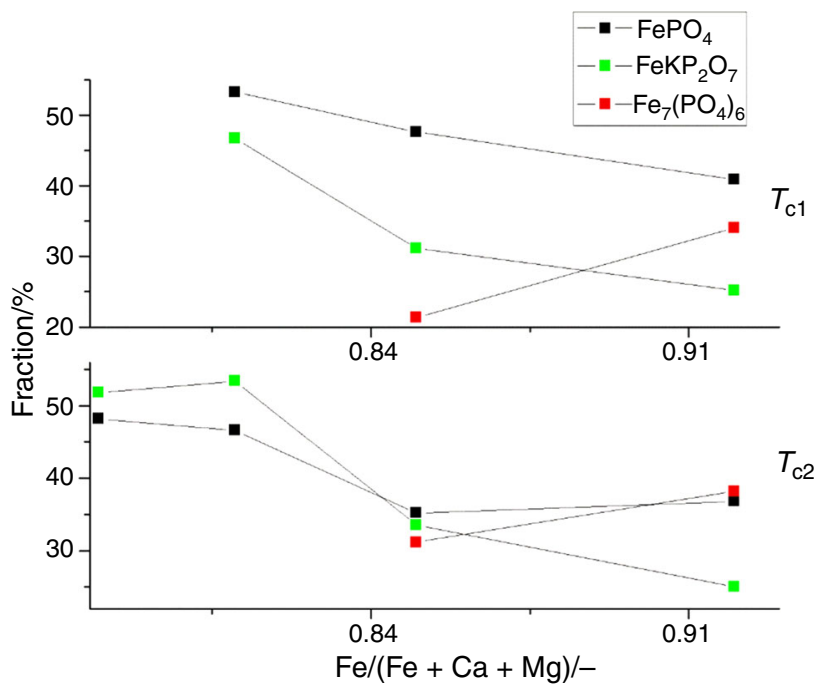

Fig. 5 Graphical presentation of results of Rietveld analysis for $30 \mathrm{Fe} 41 \mathrm{P} \quad(\mathrm{Fe} /(\mathrm{Fe}+\mathrm{Ca}+\mathrm{Mg})=0.78), 32 \mathrm{Fe} 41 \mathrm{P} \quad(\mathrm{Fe} /(\mathrm{Fe}+\mathrm{Ca}+$ $\mathrm{Mg})=0.81), 35 \mathrm{Fe} 41 \mathrm{P}(\mathrm{Fe} /(\mathrm{Fe}+\mathrm{Ca}+\mathrm{Mg})=0.85), 40 \mathrm{Fe} 41 \mathrm{P}(\mathrm{Fe} /$ $(\mathrm{Fe}+\mathrm{Ca}+\mathrm{Mg})=0.92)$

polymerization degree. It implies that ferric ions may exhibit the cross-linking character and also leads to the progressive ordering of the structure. 


\section{Thermal stability of iron phosphate-silicate glasses}

In order to express thermal stability of iron phosphatesilicate glasses, characteristic temperatures associated with thermal effects were designated through DSC curves. $\Delta T\left[{ }^{\circ} \mathrm{C}\right]$ and $K_{\mathrm{W}}[-]$ parameters [23] were calculated accordingly to Eqs. 1 and 2. Results are included in Table 2 and in Fig. 6.

$\Delta T=T_{\mathrm{c} 1}-T_{\mathrm{g}}$

$K_{\mathrm{W}}=\left(T_{\mathrm{c} 1}-T_{\mathrm{g}}\right) / T_{\mathrm{m}}$

It can be concluded that with gradual iron (III) oxide incorporation, $\Delta T$ and $K_{\mathrm{W}}$ are influenced and the general tendency to decrease is revealed. Significantly polymerized $2 \mathrm{Fe} 41 \mathrm{P}$ glass with $\mathrm{Fe} /(\mathrm{Fe}+\mathrm{Ca}+\mathrm{Mg})$ ratio as 0.08 possesses the improved thermal stability and reduced susceptibility to crystallization $\left(\Delta T=163{ }^{\circ} \mathrm{C}\right.$ and $\left.K_{\mathrm{W}}=0.18\right)$ compared to $30 \mathrm{Fe} 41 \mathrm{P}$ glass $\left(\Delta T=107^{\circ} \mathrm{C}\right.$ and $K_{\mathrm{W}}=0.12$, $\mathrm{Fe} /(\mathrm{Fe}+\mathrm{Ca}+\mathrm{Mg})=0.78)$.

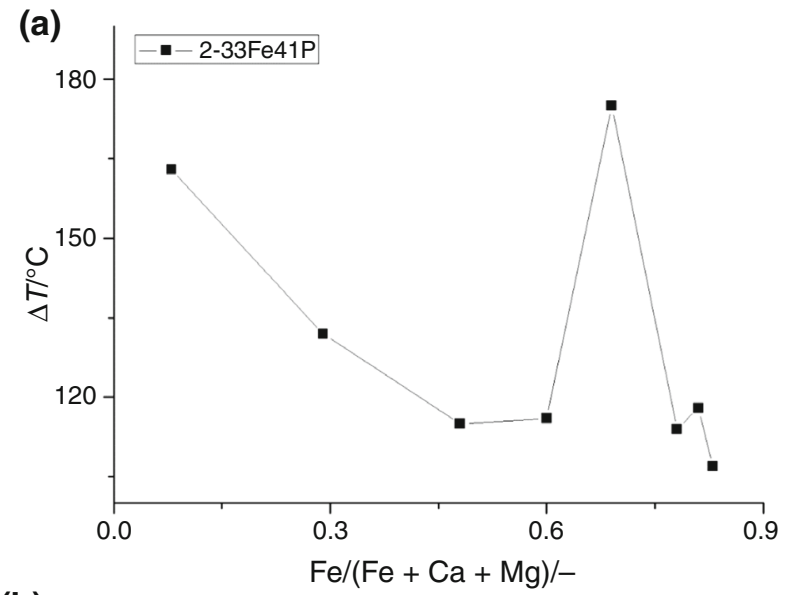

(b)

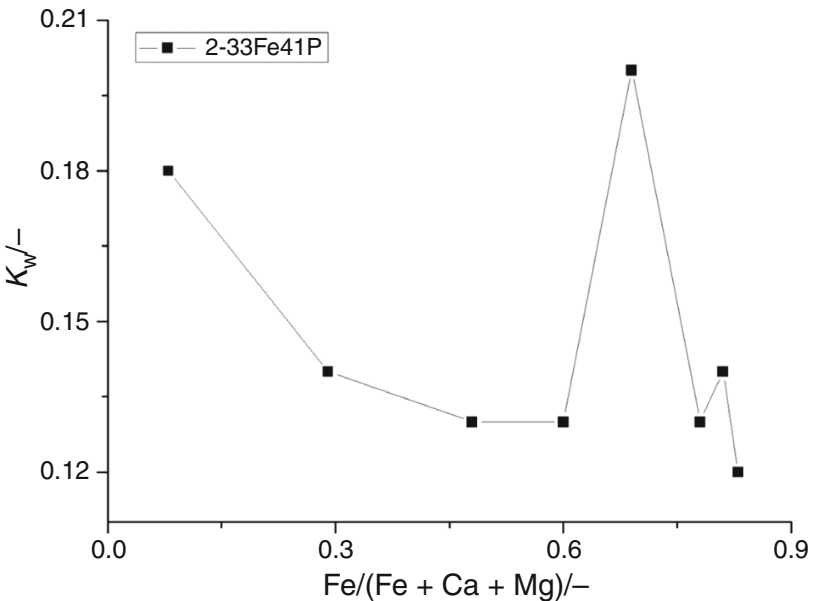

Fig. 6 Graphical representation of thermal stability parameters calculated from Eqs. 1 (a) and 2 (b)
It needs to be noted that $25 \mathrm{Fe} 41 \mathrm{P}$ glass with matched 0.69 as value of $\mathrm{Fe} /(\mathrm{Fe}+\mathrm{Ca}+\mathrm{Mg})$ ratio does not follow this trend, and it reveals surprisingly superior thermal stability in comparison with glasses with lower $\mathrm{Fe}_{2} \mathrm{O}_{3}$ addition, manifested by higher values of $\Delta T$ and $K_{\mathrm{W}}$ parameters equal to $175{ }^{\circ} \mathrm{C}$ and 0.20 . It is directly connected to reflected alterations in DSC curves and as it was ascribed, the effect of crystallization of $\mathrm{Fe}_{3}\left(\mathrm{PO}_{4}\right)_{2}$ phase is crucial.

The general tendency to decrease thermal stability parameters was maintained with extension of consideration to glass-crystalline materials for which the designation of glass transition temperatures was possible $(35 \mathrm{Fe} 41 \mathrm{P}$ and 40Fe41P).

\section{Conclusions}

Glass formation in $\mathrm{P}_{2} \mathrm{O}_{5}-\mathrm{SiO}_{2}-\mathrm{K}_{2} \mathrm{O}-\mathrm{MgO}-\mathrm{CaO}-\mathrm{Fe}_{2} \mathrm{O}_{3}$ system was evaluated. $33 \mathrm{~mol} \%$ addition was estimated as the limit value of $\mathrm{Fe}_{2} \mathrm{O}_{3}$ which enables to obtain a fully amorphous material. Further iron ions implementation conduces to the increase in the level of crystallinity. Nevertheless, the designated content of amorphous phase in $40 \mathrm{Fe} 41 \mathrm{P}(81.5 \%)$ and $45 \mathrm{Fe} 41 \mathrm{P}(78.4 \%)$ glass-crystalline materials is still tremendous. Nevertheless, the glassforming region is considerably wide.

Results of DSC, XRD and SEM-EDS analysis indicated that silicon ions are presumably more associated with amorphous phase detected in all analyzed samples. More energy is required for breaking of $\mathrm{Si}-\mathrm{O}$ bonds due to greater elasticity, manifested itself through the value of $\mathrm{iG}$ parameter, compared to $\mathrm{P}-\mathrm{O}$ bond which simultaneously clarifies this phenomenon.

Calcium magnesium diphosphate, iron potassium diphosphate and iron (III) phosphate are considered as frequently appearing phases. $\mathrm{CaMgP}_{2} \mathrm{O}_{7}$ was detected after induced crystallization in analyzed samples characterized by $\mathrm{Fe} /(\mathrm{Fe}+\mathrm{Ca}+\mathrm{Mg})$ parameter not exceeded 0.60 value (20Fe41P). Thus, products enriched with calcium and magnesium ions are not observed in samples prepared from glasses containing less than $16.2 \mathrm{~mol} \% \mathrm{MgO}$ and $10.8 \mathrm{~mol} \% \mathrm{CaO}$ and more than $20 \mathrm{~mol} \% \mathrm{Fe}_{2} \mathrm{O}_{3}$. Parallelly, $\mathrm{FeKP}_{2} \mathrm{O}_{7}$ is identified in every sample with $\mathrm{Fe} /(\mathrm{Fe}+$ $\mathrm{Ca}+\mathrm{Mg}$ ) ratio higher than 0.16 . It is associated with the appearance of phosphates which are less polymerized compared to the $\mathrm{KMg}\left(\mathrm{PO}_{3}\right)_{3}$ and $\mathrm{Mg}_{2}\left(\mathrm{PO}_{3}\right)_{4}$ phases observed in $4 \mathrm{Fe} 41 \mathrm{P}$ sample. The inherence of $\mathrm{FePO}_{4}$ was confirmed for glasses and glass-crystalline materials containing at least $30 \mathrm{~mol} \% \mathrm{Fe}_{2} \mathrm{O}_{3}$. It is presumable that magnesium-rich and calcium-rich phases reveal the minor tendency to crystallization compared to products enriched 
with iron ions, and it was concluded based on the alterations presented in DSC curves.

Iron (III) oxide addition leads to the decrease in the thermal stability of the glasses. However, 25Fe41P glass is characterized by significantly improved thermal stability parameters which implies it greater resistance to crystallization process. It is correlated with a crystallization of specific phase $\left(\mathrm{Fe}_{3}\left(\mathrm{PO}_{4}\right)_{2}\right)$.

In glass-crystalline materials, the presence of $\mathrm{FePO}_{4}$, $\mathrm{FeKP}_{2} \mathrm{O}_{7}$ and $\mathrm{Fe}_{7}\left(\mathrm{PO}_{4}\right)_{6}$ phases was also stated due to proceeding with induced crystallization in samples containing 35 and $40 \mathrm{~mol} \% \mathrm{Fe}_{2} \mathrm{O}_{3}$. It is consistent with results obtained for $45 \mathrm{Fe} 41 \mathrm{P}$. The amount of $\mathrm{Fe}_{7}\left(\mathrm{PO}_{4}\right)_{6}$ is increasing at the expense of $\mathrm{FePO}_{4}$ and $\mathrm{FeKP}_{2} \mathrm{O}_{7}$. It is presumably combined with proceeding of the ordering in the structure. It may also imply the cross-linking ability manifested by iron ions.

Acknowledgements The work was supported by the Faculty of Materials Science and Ceramics AGH-University of Science and Technology No. 11.11.160.617 and the EU Project POWR.03.02.0000-I004/16.

Open Access This article is distributed under the terms of the Creative Commons Attribution 4.0 International License (http://creative commons.org/licenses/by/4.0/), which permits unrestricted use, distribution, and reproduction in any medium, provided you give appropriate credit to the original author(s) and the source, provide a link to the Creative Commons license, and indicate if changes were made.

\section{References}

1. Yin Qianwen, Kang Shuai, Wang Xue, Li Shunguang, He Dongbing, Lili Hu. Effect of $\mathrm{PbO}$ on the spectral and thermooptical properties of $\mathrm{Nd}^{3+}$-doped phosphate laser glass. Opt Mater. 2017;66:23-8.

2. Pisarski WA, Żur L, Goryczka T, Sołtys M, Pisarska J. Structure and spectroscopy of rare earth-Doped lead phosphate glasses. J Alloys Compd. 2014;587:90-8.

3. Podniesiński D, Nakielska M, Kozłowska A, Stępień R, Pysz D. Erbium, ytterbium and chromium doped phosphate glass laser. Electron Mater. 2015;43(1):4-10.

4. Hu L, He D, Chen H, Wang X, Meng T, Wen L, Hu J, Xu Y, Li S, Chen Y, Chen W, Chen S, Tang J, Wang B. Research and development of neodymium phosphate laser glass for high power laser application. Opt Mater. 2017;63:213-20.

5. Stoch P, Stoch A, Ciecińska M, Krakowiak I, Sitarz M. Structure of phosphate and iron-phosphate glasses by DFT calculations and FTIR/Raman spectroscopy. J Non-Cryst Solids. 2016;450:48-60.
6. Ojovan MI, Lee WE. Immobilisation of radioactive waste in glass. In: Ojovan MI, Lee WE, editors. An introduction to nuclear waste immobilisation. 2nd ed. Amsterdam: Elsevier; 2014. p. $245-82$.

7. Wacławska I, Szumera M. Fosforanowe materiały ceramiczne do immobilizacji kadmu w środowisku glebowym. Ceram Mater. 2011;63(2):407-12.

8. Sales BC. Phosphate glasses. Mater Res Soc. 1987;12:32-4.

9. Brow RK. Review: the structure of simple phosphate glasses. J Non-Cryst Solids. 2000;263\&264:1-28.

10. Abou Neel EA, Ahmed I, Pratten J, Nazhat SN, Knowles JC. Characterisation of antibacterial copper releasing degradable phosphate glass fibres. Biomaterials. 2005;26:2247-54.

11. Ahmed I, Shaharuddin SS, Sharmin N, Furniss D, Rudd C. Core/clad phosphate glass fibres containing iron and/or titanium. Biomed Glasses. 2015;1:20-30.

12. Mishra A, Rocherullé J, Massera J. Ag-doped phosphate bioactive glasses: thermal, structural and in vitro dissolution properties. Biomed. Glasses. 2016;2:38-48.

13. Yang JH, Park H-S, Cho Y-Z. Silver phosphate glasses for immobilization of radioactive iodine. Ann Nuclear Energy. 2017;110:208-14.

14. Stoch P, Szczerba W, Bodnar W, Ciecińska M, Stoch A, Burkel E. Structural properties of iron-phosphate glasses: spectroscopic studies and ab initio simulations. Phys Chem Chem Phys. 2014;16(37):19917-27.

15. Sales BC, Ramsey RS, Bates JB, Boatner IA. Investigation of the structural properties of lead-iron phosphate glasses using liquid chromatography and raman scattering spectroscopy. J Non-Cryst Solids. 1986;87:137-58.

16. Doupovec J, Sitek J, Kakos J. Crystallization of iron phosphate glasses. J Therm Anal. 1981;22:213-9.

17. Li HJ, Liang XF, Yu HJ, Yang DQ, Yang SY. Studies of structure of calcium-iron phosphate glasses by infrared, Raman and UVVis spectroscopies. Indian J Phys. 2016;90(6):693-8.

18. Mošner $\mathrm{P}$, Račický A, Koudelka L. Thermal properties and crystallization of $\mathrm{MgO}-\mathrm{FeOx}-\mathrm{P}_{2} \mathrm{O}_{5}$ glasses. J Thermal Anal Calorimet. 2018;132(2):843-50.

19. Kuczek J, Jelen P, Stoch P, Błachowski A, Wacławska I, Szumera M. Raman and Mossbauer studies of iron phosphate-silicate glasses. J Mol Struct. 2018;1170:82-9.

20. Görlich E. The effective nuclear charges and the electronegativity. Kraków: Polish Academy of Art and Science; 1997.

21. Stoch L. Structure and crystallization of multicomponent glasses. Proc Int Congr Glass. 2001;1:62-73.

22. Liebau $F$. The influence of cation properties on the conformation of silicate and phosphate anions. In: Navrotsky A, O'Keeffe M, editors. Structure and bonding in crystals. Cambridge: Academic Press; 1981. p. 198.

23. Ma L, Brow RK, Ghussn L, Schlesinger ME. Thermal stability of $\mathrm{Na}_{2} \mathrm{O}-\mathrm{FeO}-\mathrm{Fe}_{2} \mathrm{O}_{3}-\mathrm{P}_{2} \mathrm{O}_{5}$ glasses. $\mathrm{J}$ Non-Cryst Solids. 2015;409:131-8.

Publisher's Note Springer Nature remains neutral with regard to jurisdictional claims in published maps and institutional affiliations. 